\title{
LIEPĀJNIEKI TEODORS UN NIKOLAJS BREDŽI-BRIEŽI UZNĒEMĒJDARBĪBĀ UN INŽENIERZINĀTNĒS
}

\section{LĀSMA GAITNIECE**}

Rīgas Tehniskā universitāte

Kopsavilkums. Raksts veltīts liepājniekiem Teodoram un Nikolajam BredžiemBriežiem. Tēvs Teodors Bredžs-Briedis bija uzṇēmējs Liepājā. Viṇa dēls Nikolajs, Latvijas Universitātes Kīmijas fakultātes absolvents (1936), Otrā pasaules kara beigās devās emigrācijā un nonāca Amerikas Savienotajās Valstīs. Nikolajs Bredžs-Briedis izveidoja spožu zinātnieka karjeru - viṇa pētniecības darbs metālu metināšanas nozarē 1955. gadā tika novērtēts ar Amerikas Metinātāju biedrības Linkolna zelta medaḷu, 1956. gadā - ar Amerikas Latviešu apvienības Kultūras fonda Goda diplomu par sasniegumiem zinātnē, tajā pašā gadā zinātnieks tika uzṇemts ASV Zinātnieku un pētnieku Goda biedrībā. Nikolajs Bredžs-Briedis ir saṇēmis 27 patentus un ir 14 zinātnisko publikāciju autors.

Atslēgas vārdi: Teodors Bredžs-Briedis, Nikolajs Bredžs-Briedis, uzṇēmējdarbība, inženierzinātnes.

\section{Ievads}

Liepājas uzṇēmēja Teodora Bredža-Brieža vārds ir mazpazīstams pat liepājniekiem. Plašākai sabiedrībai maz zināma ir arī viṇa dēla, latviešu inženiera Nikolaja Bredža-Brieža profesionālā darbība un paveiktais metalurgijā. Inženiera N. Bredža-Brieža dzīvesstāsts ir līdzīgs daudzu citu latviešu, kuri Otrā pasaules kara laikā devušies emigrācijā, biogrāfijām. Tālu prom no savas un vecāku dzimtenes viṇam bija jāveido dzīve un vēlreiz, nemitīgi pierādot savas prasmes un izcilību, arī karjera. Tā, ilgus gadus dzīvojot Amerikas Savienotajās Valstīs, izvērtās l,oti veiksmīga. Emigrācijā nav daudz latviešu zinātnieku, kuri pēckara gados saistībā ar savu pētniecības darbību spējuši gūt tik ievērojamus panākumus un saṇēmuši atzinību pasaulē.

* Korespondējošais autors.

E-pasts: lasma.gaitniece@rtu.lv 
Raksta sagatavošanā izmantoti Latvijas Valsts vēstures arhīva materiāli un Latvijas bibliotēku krājums, kā arī publikācijas pirmās neatkarīgās Latvijas Republikas un emigrācijas latviešu laikrakstos.

\section{Kinoteātra īpašnieks Teodors Bredžs-Briedis (1885-1940)}

Teodors Matīsa dēls Bredžs-Briedis dzimis 1885. gada 30. janvārī Gulbenē [1]. Otrs viṇa kristītais vārds ir Gothards, ko parasti ikdienā nelietoja, un tas parādās vien dokumentos, piemēram, viṇa Latvijas ārzemju pasē [2]. Citām šīs dzimtas personām uzvārds dažādos dokumentos atveidots vairākās versijās (Bredžs, Bredšs, Bredže, Bredž-Briede, Bredže-Briedis), neievērojot konsekvenci.

Informāciju par Teodora Bredža-Brieža vecākiem, bērnību un iemesliem, kādēl ǵimene no Gulbenes aizbraukusi, autorei nav izdevies iegūt, taču ir iespējams konstatēt, ka Liepājā vinš̌ ieradies pēc Pirmā pasaules kara un veiksmīgi sācis veidot savu karjeru uzñēmējdarbībā. Starpkaru periodā Teodors Bredžs-Briedis bijis Liepājā iecienītā kinoteātra «Viktorija», kas dibināts 1922. gadā un atradās Graudu ielā 36, vienīgais īpašnieks, pārṇemot tā vadību no savas dzīvesbiedres Elizabetes BredžsBriedis tēva Kārḷa Fišera [3]. Turklāt «Viktorija» bijis vienīgais kinoteātris visā Liepājā, kas piederējis latviešu ǵimenei [4]. Teodors Bredžs-Briedis nebaidījās pienemt izaicinājumus un riskēt.

Ir nepārprotami skaidrs, ka Bredžu-Briežu ǵimene finansiāli bijusi l’oti labi situēta. Uz to norāda arī kāds fakts, kas pētniekam liek uzdot jautājumus. Teodors un Elizabete Bredži-Brieži 1924. gada 19. jūnijā pie Liepājas notāra Žaṇa Kaupiṇa noslēguši līgumu (reǵistrs Nr. 3596), kas atcel laulāto mantas kopību. Iepriekš Teodors Bredžs-Briedis no dzīvesbiedres Elizabetes bija saṇēmis pārvaldīšanā dažādu kustamu mantu (mēbeles, vel̦as drēbes, zelta un sudraba lietas, saimniecības piederumus), kopējā vērtībā ap 4000 latu. Pēc šī līguma noslēgšanas iepriekš minētā manta pārgāja Elizabetes atsevišḳā īpašumā [5]. Domājams, ka tie bija riski, kas saitīti ar uzñēmējdarbību.

N̦emot vērā Teodora Bredža-Brieža darbības daudzpusīgumu, apzīmējums «uzñēmējs» nebūs īsti precīzs. Viṇa profesionālo darbību iespējams raksturot ar epitetu «radoša». Šāds apzīmējums saistībā ar uzṇēmējiem un namsaimniekiem attiecināms reti, taču, plašāk izpētot T. Bredža-Brieža biogrāfiju, jāatzīst, ka viņš to patiešām ir pelnījis. 1939. gadā, sagaidot kinoteātra «Viktorija» 15 gadu jubileju, laikraksts «Kurzemes Vārds» par tā īpašnieku rakstīja: «Atgriezies pēc pasaules kara Latvijā kā atvaḷinātais pulkvežleitnants, Bredže-Briedis iestājies Liepājas muitnīcā kā eksperts, bet vēlāk pārṇēma no sava sievas 
tēva kino vadību un ar mazu pārtraukumu vadījis to līdz pat šai dienai. Pēc 1934. gada viṇš dzīvi piedalījies arī filmu nozarē, nodibinot Rīgā K.-S. «Līgo-filma». Bredžs-Briedis ir Liepājas namsaimnieku biedrības biedrs un Liepājas Annas draudzes ilggadīgs padomes loceklis» [6]. Teodors Bredžs-Briedis kinoteātri vadīja līdz mūža beigām. Domājams, ka viņš aizsaules ceḷos devās jau 1940. gadā, jo 1941. gada Tautas skaitîšanas dokumentos T. Bredža-Brieža vārds vairs neparādās [7]. Kinoteātris «Viktorija» darbojās arī Otrā pasaules kara laikā, to vadīja T. BredžaBrieža atraitne Eiženija Bredžs-Briede. 1944. gada februārī tam izsita skatlogu un nozaga kino reklāmas fotouzñēmumus [8]. Pēc Otrā pasaules kara, padomju varas gados, kā visi privātie uzṇēmumi, kinoteātris tika nacionalizēts.

Ne mazāk aktīvi Teodors Bredžs-Briedis kopa arī savu garīgo dzīvi, kalpodams Liepājas Svētās Annas evangéēliski luteriskajā baznīcā. 1940. gadā draudzes padomes locekḷu vidū radās doma, ka par draudzes priekšnieku varētu iecelt šajā baznīcā kalpojošo mācītāju Dr. Visvaldi Sanderu. Šāds lūgums ticis iesniegts baznīcas virsvaldē Rīgā, taču tur arhibīskapa Dr. Teodora Grīnberga vadībā to 1940. gada 12. marta sēdē noraidīja, pamatojot, ka mācītājs var būt savas draudzes valdes loceklis, taču nevar būt tās priekšsēdētājs, respektīvi, draudzes priekšnieks [9]. Lai situāciju risinātu, bija jāmeklē enerğisks cilvēks no pašas draudzes locekḷu vidus. Tāds arī tika atrasts: 1940. gada pavasarī par Liepājas Svētās Annas evangéēliski luteriskās draudzes priekšnieku kḷuva Teodors Bredžs-Briedis [10].

\section{Teodora Bredža-Brieža dibināts cirks}

Domājams, veiksmīgā uzṇēmējdarbība izklaides nozarē bija iemesls Teodora Bredža-Brieža iecerei Liepājā vadīt ne vien kinoteātri, bet arī cirku. Liepājnieki ar cirka mākslu bija iepazinušies jau iepriekš. Turklāt tā, cik secināms no periodikas izdevumiem un vēstures avotiem, vinus ḷ loti aizrāvusi. Ārkārtīgi populārs bijis cirks, kas ik gadu no 8. līdz 16. augustam noticis Annas gadatirgū Jaunliepājā. Gadatirgus tradīcija tur aizsākusies pirms Pirmā pasaules kara un pastāvējusi ilgus gadu desmitus, arī starpkaru laikā. To bija l’oti iecienījuši ne tikai liepājnieki, bet arī visas Kurzemes iedzīvotāji. L̦audis jau loti laikus esot atprasījušies no darba, lai tikai augusta otrā nedēḷa vai vismaz kāda diena, ja vairāk nebija iespējams, būtu brīva. Cilvēki ar ilgošanos un nepacietību gaidījuši, kad beidzot būs gadatirgus ar tā neatṇemamu sastāvdạ̣u ugunsrijēju, cīkstoṇu, klaunu un savvaḷas dzīvnieku priekšnesumiem [11]. Latvijas cirka vēstures pētnieks G̣irts Dzenītis gadatirgu Jaunliepājā un cirka mākslinieku priekšnesumus tā laikā attēlojis kolorīti: «Liepājā 
vasarās Annas dienas tirgi ilga pusmēnesi. Bija visādi preču izstrādājumi, kurus katrs tirgotājs reklamēja, kā prata. .. No agra rīta līdz pusnaktij spēlēja «misinggrauzēji», reproduktoros čerkstēja jaunākie šlāgeri, neiztika arī bez leijerkastēm. Kauca un rēca plēsīgie zvēri. Artisti jutās kā īsta tirgus publika [12].»

Bez cirka mākslinieku priekšnesumiem gadatirgus laikā liepājniekiem bija iespējams apmeklēt pat vairākus stacionāros cirkus. Pirms Pirmā pasaules kara Aleksandra ielā 14/16 (tagad Brīvības iela) atradās viens no pirmajiem Liepājas cirkiem, savukārt 20. gadsimta 20. gados Vecajā Ostmalā, siļ̧̣u brāḳī, tika izveidots vēl viens.

1. attēls. Liepājas osta

20. gadsimta sākumā [13].

2. attēls. Cirka izbūves projekts siḷ̂,ku brākī Liepājā (1923) [14].
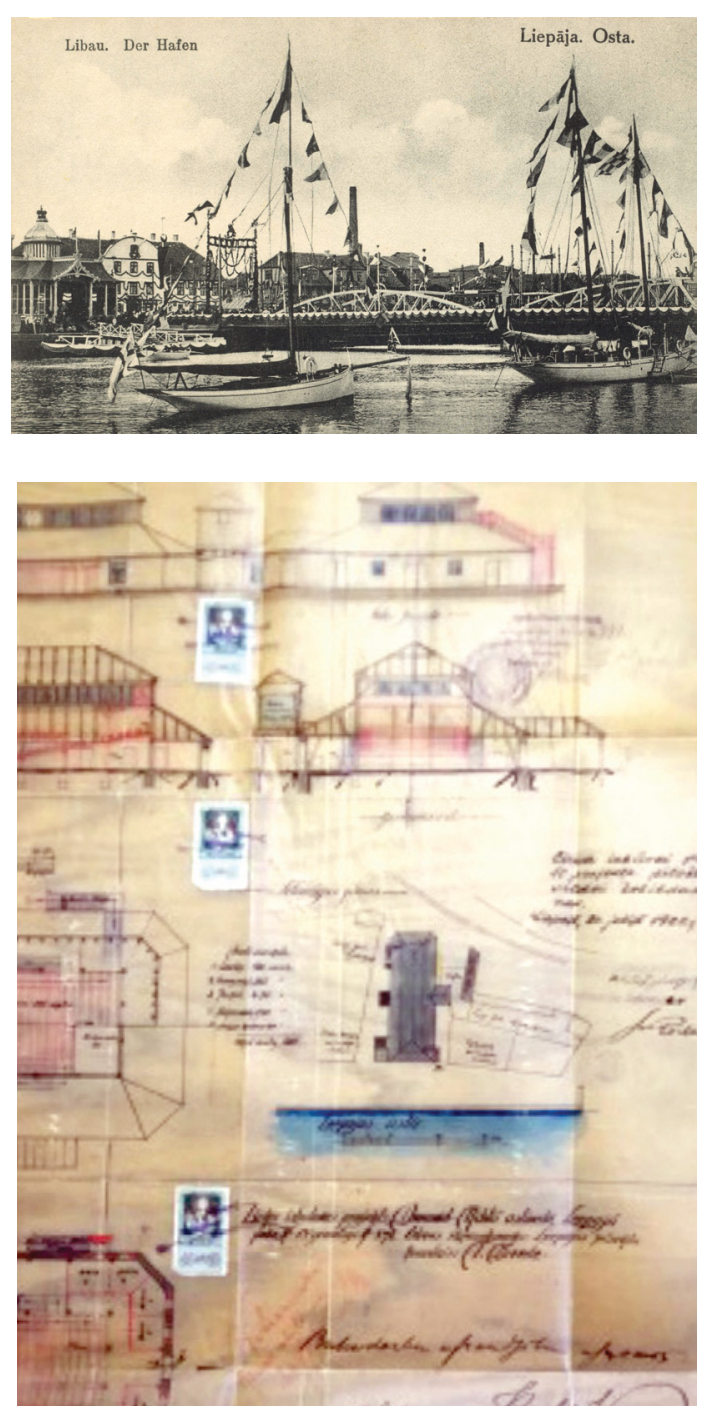

Liepājnieki

Teodors un Nikolajs Bredži-Brieži

uzṇēmējdarbībā un inženierzinātnēs 
Pilsētai piederošais siḷ,ku brāḳis netika izmantots, un no 1923. gada 10. jūlija Teodors Bredžs-Briedis to sāka nomāt, nomas tiesības sākotnēji iegūstot uz trim gadiem. Jau 1923. gada 18. jūlijā uzñēmējs Iekšlietu ministrijas Būvvaldei Rīgā nosūtīja nepieciešamos dokumentus, lai iegūtu brāksa pārbūves atḷauju cirka vajadzībam. Darbus bija plānots pabeigt līdz 15. augustam. Pārbūves darbus uzraudzīja būvuznēēējs, Rīgas Politehniskā institūta (RPI) Inženieru nodaḷas absolvents (1912) Kārlis Vinkmanis (1888-1942) [14].

Latvijas Valsts Vēstures arhīva dokumenti liecina par siļ̣u brāḳa pārbūvi un tās norisi. Tā bija vienstāva mūra ēka, celta no kjieǵel̦iem. Cirka telpas ierīkoja 1000 skatītājiem, tajās nebija apkures, jo cirka izrādes paredzēja rīkot tikai vasarā [15].

1923. gada 16. septembrī pārbūvēto siḷ̦u brāḳi apmeklēja komisija Liepājas prefekts Kārlis Šteinerts, Liepājas pilsētas galvas v. i. Pēteris Stiprais un būvvaldes priekšnieks inženieris Eižens Kolpaks. Starp citu, viens no komisijas locekḷiem, Eižens Kolpaks (1885-1926), bija RPI Inženieru nodaḷas absolvents (1911). Komisijas slēdzienā lasām, ka, apskatot T. Bredža-Brieža izbūvēto cirka ēku Liepājā, Dienvidrītu ostmalā 14, nolemts būvi «atzīt par pareizi izdarītu un ațaut uzsākt darbību [16].» Siḷ kưu brāksa pārbūves atbilstību cirka vajadzībām apliecina arī būvvaldes priekšnieka Eižena Kolpaka un darbveža Jāṇa Cerika parakstītā Iekšlietu ministrijas Būvvaldes apliecība par būvdarbu nobeigšanu.

Cirks ar krāšñām izrādēm un pat kavalkādēm pa Liepājas ielām tika atklāts tūlīt pēc būvdarbu beigšanas. Tie bija svētki, kas izsauca neviltotu liepājnieku sajūsmu. «Cirka laikā te risinājās interesanti notikumi - tā darbības uzsākšanu ievadīja milzīga reklāma trīs vai četru nedēlu garumā, vēstot, ka gaidāms milzīgs pārsteigums. Un tas tik tiešām bija, jo pirmajās izrādes minūtēs skatītājiem tika nodemonstrēts priekšnesums ar 20 dresētiem zirgiem, nekas jau tur sevišks droši vien nebija, bet tajos laikos pievilka skatītājus [17].» Liepājnieku prieki nebija ilgi, jo cirks bankrotēja jau 1928. gadā, sākoties ekonomiskajai krīzei. Pēc krīzes siḷku brāksis nonāca aizsargu rokās, un tajā tika ierīkota šautuve. Ēkas vecās konstrukcijas daḷēji saglabājušās līdz mūsdienām.

Jāpiebilst, ka Bredža-Brieža gimene īrēja dzìvokli Graudu ielā 36 un ziṇu par ǵimenes īpašumiem Liepājā nav. Acīmredzot, uzṇēmēja peḷna nav bijusi liela.

\section{Inženieris Nikolajs Bredžs-Briedis (1909-1989)}

Teodora Bredža-Brieža laulībā ar Elizabeti Fišeri 1909. gada 29. oktobrī Liepājā piedzima dēls Nikolajs [18]. Viṇš tēva pēdās nesekoja un par uzṇēmēju nekḷuva, taču Nikolaju Bredžu-Briedi var uzskatīt par 
vienu no tiem talantīgajiem liepājniekiem, kura devums inženierzinātṇu attīstībā ir ḷoti ievērojams, taču šī cilvēka vārds līdz šim ir ticis nepelnīti aizmirsts [19].

Nikolajs Bredžs-Briedis savu pirmo izglītību ieguvis 1. Liepājas Valsts vidusskolā (reālskolā), kur mācījies no 1922. gada 21. augusta līdz 1927. gada 14. jūnijam. Sekmju izraksts mācību procesa noslēgumā liecina, ka viṇam l,oti padevušies eksaktie priekšmeti (algebra, algebriskā analīze, geometrija, fizika, k̦īmija) un arī ticības mācība, kur gūts visaugstākais vērtējums, taču ne tik labi padevušies humanitārie priekšmeti (latviešu valoda) un svešvalodu apguve (anglu un vācu valoda), kur saṇemts vien apmierinošs vērtējums [20].

3. attēls. Nikolajs Bredžš-Briedis (ap 1927) [21].

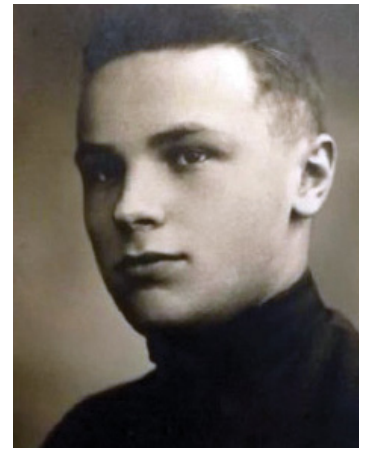

Jau 1927. gada 11. augustā Nikolajs Bredžs-Briedis Latvijas Universitātes (LU) rektoram rakstījis lūgumrakstu, kurā paudis vēlmi savu izglītību turpināt augstskolas Ķīmijas fakultātē [21]. Studijas liepājnieks absolvēja ar izcilību 1936. gadā, iegūstot inženiera k̦īmiķa grādu [22]. Jau 1937. gada sākumā jaunā inženiera vārds kopā ar viṇa studiju biedru vārdiem (Izarijs Gurevičs, Eliass Stolpers, Georgs Vītols) atrodams ar inženieru arhitektu būvtiesībām registrēto personu sarakstā, ko apstiprinājusi Iekšlietu ministrijas Būvniecības pārvalde [23]. Visi minētie inženieri absolvēja LU Ķīmijas fakultāti 1936. gadā. Būvtiesības viṇi, tostarp N. Bredžs-Briedis, ieguva, jo universitātē bija studējuši fabriku projektēšanu [24].

Pēc studijām Nikolajs Bredžs-Briedis atgriezās dzimtajā pilsētā. Jau studiju gados viṇš bija domājis par savu zināšanu izmantošanu, kas vainagojās ar patenta «Panēmiens benzīna iegūšanai no kūdras» reǵistrēšanu 1936. gada vasarā [25]. No 1938. līdz 1944. gadam jaunais inženieris strādāja Liepājas metalurǵiskajā fabrikā: sākumā par inženieri, vēlāk par laboratorijas vadītāju un vecāko inženieri. Otrā pasaules kara laikā Nikolajs Bredžs-Briedis un viṇa māsas Helēnas ǵimene Latviju pameta un devās bēglu gaitās. Vispirms viṇu ceḷš veda uz Berlīni, kur Nikolajs no 1944. līdz 1945. gadam strādāja par asistentu uzṇēmumā
Liepājnieki

Teodors un Nikolajs Bredži-Brieži uzṇēmējdarbībā un inženierzinātnēs 
«Spandauer Stahlwerke», taču tad gimene devās uz Amerikas Savienotajām Valstīm [26].

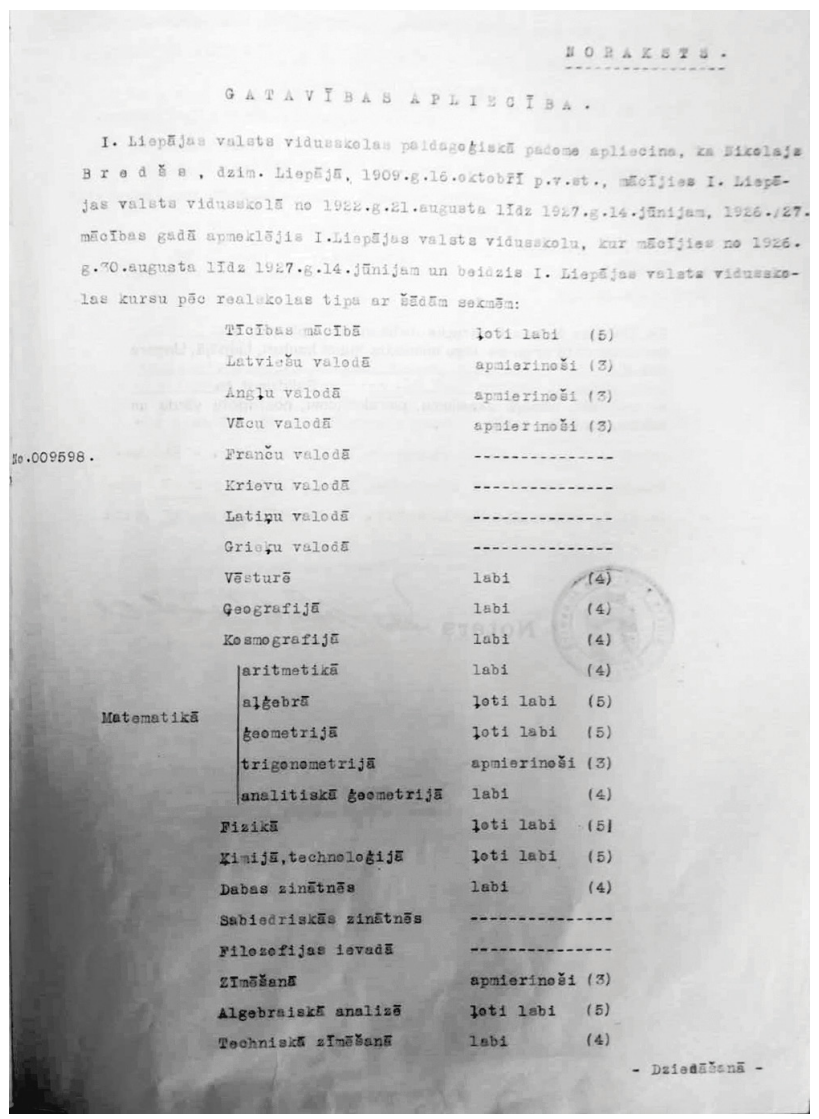

\section{4. attēls.}

Fragments no

N. Bredža-Brieža studiju grāmatinas [24].

Pirmie dzīves gadi jaunajā mītnes zemē Nikolajam Bredžam-Briedim bija grūti, jo, līdzīgi kā neskaitāmiem citiem baltiešu bēgḷiem, vinam nācās strādāt nekvalificētus darbus: apelsīnu plantācijā, par kapraci un pie cel̦a būvēm. Tikai 1951. gadā zinātniekam izdevās iegūt izglītībai atbilstošu darbu Ilinoisas Tehnoloǵiskā institūta pētniecības nodạ̦ā. Jau pēc pirmā institūtā nostrādātā gada Nikolajs Bredžs-Briedis saṇēma pirmo paaugstinājumu darbā - viṇš sāka strādāt par vecāko asistentu, vēlāk, 1953. gadā, - par docentu, 1955. gadā - par pētniecības metalurgu. 1954. gada novembrī N. Bredžs-Briedis metinātāju žurnālā «The Welding Journal» publicēja darbu «Pētījumi par faktoriem, kas nosaka stiepes pretestību augsttemperatūras metālu savienojumos». 1955. gadā par labāko publicēto darbu metālu metināšanas nozarē viṇš tika apbalvots ar Amerikas Metinātāju biedrības Linkolna zelta medaḷu un naudas 
balvu. To piešksir reizi gadā, un toreiz par to cīnījās ap 10000 zinātnieku. Toreiz medaḷu ieguva tikai ap 20 zinātnieku, tostarp Čikāgas latvietis, liepājnieks Nikolajs Bredžš-Briedis. Kā atzina godinātais inženieris, minētajā «darbā pirmo reizi tiek realizēta trīs dimensionālā noslodzēšana, kas pacel metālu stiepes pretestību trīs līdz četrkārtīgi un līdz ar to metālu pretestība tiek pacelta trauslā lūzuma plaknē» [27]. Vienlaikus tika veikti arī citi pētījumi, publicēti zinātniskie raksti. 1956. gadā N. Bredžs-Briedis sañēma Amerikas Latviešu apvienības Kultūras fonda balvu «par sasniegumiem zinātnē, kas dara godu latviešu vārdam un latviešu tautai citu tautu vidū [28].»

Viens no ievērojamākajiem Nikolaja Bredža-Brieža atklājumiem ir bišu šūnas konstrukcijas elementu izmantošana lidmašīnu un raksešu ātruma kāpināšanai. Nikolaja Bredža-Brieža izveidotās bišu šūnas plāksnes sastāvēja «no l̦oti plānām metāla plāksnītēm, kas veidotas pēc dabīgo bišu šūnu parauga. Šìs konstrukcijas elements iztur ārkārtīgi lielas slodzes un ir vairākas simts reizes vieglāks par viengabala metāla plāksnēm [29].» 1958. gadā latviešu zinātnieka biogrāfija tika iespiesta ASV ievērojamo personu enciklopēdijā «Who is Who in America». 1961. gadā N. Bredža-Brieža vārds tika iekḷauts enciklopēdijā «American Men of Science» [30].

Tieši ASV Nikolajam Bredžam-Briedim izdevās gūt vislielākos panākumus zinātnē, ko apliecina 27 iegūtie patenti un 14 zinātnisko darbu publikācijas. Līdz 1965. gadam viṇš darbojās metalurǵijas pētnieka amatā Ilinoisas Tehnoloǵiskajā institūtā Čikāgā, bet no 1965. gada sabiedrībā «Wall Colmony» Detroitā.

Par saviem atklājumiem zinātnē Nikolajs Bredžs-Briedis vairākkārt ir publiski iepazīstinājis sabiedrību, lasot lekcijas, piemēram, 1960. gadā Masačūsetsas Tehnologiju institūta vasaras sesijā viṇš lasījis vairākas lekcijas par metālu cietlodēšanu [31].

Kaut arī Nikolajs Bredžs-Briedis nesekoja tēva pēdās, izvēlēdamies kḷūt nevis par uzṇēmēju, bet gan zinātnieku, vinus vienoja ticība Dievam. Nikolajs pēc ierašanās ASV par spīti lielajai aizṇemtībai aktīvi darbojās Čikāgas Ciānas draudzē, kur kādu laiku bija pat padomes priekšsēdētājs [32].

Ilgus gadus inženieris $\mathrm{N}$. Bredžs-Briedis savu ǵimeni neveidoja. Tikai 1963. gada vasaras nogalē viṇš salaulājās ar kurzemnieci veterinārārsti Liliju Freimani (1914-1997), kura veterinārmedicīnas studijas 1942. gadā sāka Rīgā [33] un pabeidza ārzemēs. 


\section{Nobeigums}

Noslēgumā piebilstams, ka inženieris Nikolajs Bredžs-Briedis savu dzīvi veltījis galvenokārt zinātnei, par ko plaši aprakstīts emigrācijas latviešu periodikā. Liepājā viṇa pētniecības darbs dzina vien pirmos asnus, tāpēc, acīmredzot, par talantīgo inženieri nav minēts neviens vārds ne Vladimira Čečotkina grāmatā «Metāls dzimst ugunī» [34], ne Jaroslava Dorenska grāmatā «Liepājas Metalurgs: Anno 1882». Tas nav atrodams arī izdevumā «Liepājnieku biogrāfiskā vārdnīca» [35]. Neraugoties uz novadnieku «aizmāršību», Nikolajs Bredžs-Briedis ķīmijas vēsturē pazīstams kā jaunas metodes ieviesējs cermeta ražošanā, dažādu cietlodēšanas un trauslo metālu lūzumu problēmu pētnieks, metalurǵijas speciālists, kura vārds ir pazīstams pasaulē. Viṇa vārds, neapšaubāmi, ierindojams izcilāko latviešu zinātnieku vidū. Inženiera Nikolaja BredžaBrieža dzīve noslēdzās 1989. gada 2. maijā Barringtonā, Ilinoisas štatā, ASV [36].

\section{AVOTU UN LITERATŪRAS SARAKSTS}

[1] Tiesu sludinājumi. Valdības Vēstnesis, Nr. 30, 5. lpp.

[2] Tiesu sludinājumi. Liepājas prefektūras paziṇojums. Valdības Vēstnesis, Nr. 245, 5. lpp.

[3] Tiesu sludinājumi. Valdības Vēstnesis, Nr. 30, 5. lpp.

[4] «Kurzemē» - Liepājas kinoteātri pirms 2. pasaules kara. Pieejams: https://www.irliepaja.lv/lv/raksti/kultura/kurzeme-liepajas-kinoteatri-pirms-2pasaules-kara/ Liepājas ziṇu portāls irLiepaja.lv. [skatīts: 06.10.2017.]

[5] Liepājas apgabaltiesa. Valdības Vēstnesis, 1924, Nr. 177, 5. lpp.

[6] Liepājas dzīve. Kurzemes Vārds, 1939, Nr. 30, 6. lpp.

[7] Latvijas Valsts vēstures arhīvs (LVVA) 1308. f., 15. apr., 2951. l., 82. o. p. lp. Tautas skaitīšanas dati Liepājā, Graudu ielā 36, 1941. g.

[8] Zādzības. Kurzemes Vārds, 1944, Nr. 38, 4. lpp.

[9] Ziṇas no garīgas un laicīgas dzīves. Baznīcas virsvalde. Svētdienas Rīts, 1940, Nr. 17, 5. lpp.

[10] Mācītājs nevar būt draudzes priekšnieks. Kurzemes Vārds, 1940, Nr. 83, 5. lpp.

[11] Gaitniece, L. Rudzu mēneša prieki Annas gadatirgū. Kursas Laiks, 2017, Nr. 32, 21. lpp.

[12] Dzenītis, G̦. Latviešu cirka vēstures lappuses. Rīga: Liesma, 1981, 24. lpp.

[13] Fotogrāfija no autores personīgā arhīva.

[14] LVVA 6343. f., 8. apr., 141. l., 1.-6. lp. Teodora Bredža-Brieža lūgums Iekšlietu ministrijas Būvvaldei ar cirka izbūves projektu pielikumā, 1923. g.

[15] LVVA 6343. f., 8. apr., 141. 1., 6. lp. Teodora Bredža-Brieža paskaidrojumi Iekšlietu ministrijas Būvvaldei, 1923. g. 
[16] LVVA 6343. f., 8. apr., 141. l., 5., 9. lp. Būvvaldes slēdziens pēc pārbūvētā siḷ̦u brāksa apmeklējumu un par būvdarbu nobeigšanu, 1923. g.

[17] Pelcmane, S. Kanāls - Liepājas aizsērējusī zelta dzīsla. Kurzemes Vārds, 2002, Nr. 37, 6. lpp.

[18] LVVA 7427. f., 1. apr., 11103. l., 2. Ip. Nikolaja Bredža-Brieža dzimšanas un kristīšanas apliecības noraksts.

[19] Gaitniece, L. Cirks siḷku brāḳī. Kursas Laiks, 2017, Nr. 33, 21. Ipp.

[20] LVVA 7427. f., 1. apr., 11103. 1., 5. lp. Nikolaja Bredža-Brieža gatavības apliecības noraksts.

[21] LVVA 7427. f., 1. apr., 11103. l., 1. lp. Nikolaja Bredža-Brieža lūgumsraksts LU rektoram.

[22] Jauni akadēmiski izglītoti pilsoṇi. Jaunākās Ziṇas, 1936, Nr. 121, 10. lpp.

[23] Ar inženieru arķitektu būvtiesībām reǵistrēto personu 20. saraksts. Valdības Vēstnesis, 03.08.1937., Nr. 171, 2. lpp.

[24] LVVA 7427. f., 1. apr., 11103. l., 5. lp. Fragments no N. Bredža-Brieža studiju grāmatinnas.

[25] Patentu ziṇas. Valdības Vēstnesis, 1936, Nr. 207, 4. lpp.

[26] Latvieši techniskā darbā. Technikas Apskats, 1969, Nr. 55, 30. lpp.

[27] Nav jau nekas seviškss sasniegts. Laiks, 1955, Nr. 84, 6. lpp.

[28] Latvieši techniskā darbā. Technikas Apskats, 1969., Nr. 55, 30. lpp.

[29] Latvieši aizjūrā. Latvija, 1959, Nr. 12, 5. lpp.

[30] Latvieši techniskā darbā. Technikas Apskats, 1969, Nr. 55, 30. lpp.

[31] Latvieši techniskā darbā. Technikas Apskats, 1960., Nr. 28, 24. lpp.

[32] LVVA 7427. f., 2. apr., 1590. l. Universitātes Rīgā studentes Lilijas Freimanes personāllieta, 1942.-1944. g.

[33] Čečotkins, V. Metāls dzimst ugunī. Rīga: Avots, 1982, 170. lpp.

[34] Dorenskis, J. Liepājas Metalurgs: Anno 1882. Liepāja: Liepājas metalurgs, 2012, 436 lpp.

[35] Tooms, V. (sast). Liepājnieku biogrāfiskā vārdnīca. Liepāja: biedrība «Optimistu pulks», 2012, 400 lpp.

[36] [Piederīgo paziņojums]. Laiks, 1989, Nr. 38, 7. lpp.

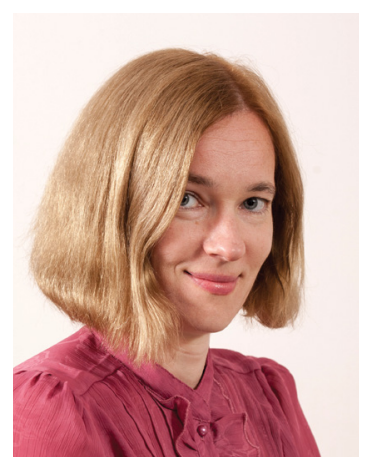

LĀSMA GAITNIECE, Mg. philol., graduated from Liepaja Pedagogical Academy in 2005. She received a professional degree in Public Relations from Liepaja University in 2012. She is currently a Latvian language instructor, researcher and administrator of the office of Dean of the Faculty of ELearning Technologies and Humanities of Riga Technical University. She is a member of the Association of Journalists (Republic of Latvia) and of the European Latvian Association. She is an author of multiple publications and several textbooks. She has been a guest lecturer in Latvian as a foreign language courses at Savaria University Centre of the University of West Hungary (Hungary), at Johannes Gutenberg 
University of Mainz (Germany), and a teacher of Latvian as a second language in Riga 1st Medical College.

Address: 1 Kronvalda Boulevard, Riga, LV-1010, Latvia

Phone: +371 29844524

E-mail: lasma.gaitniece@rtu.lv

Lāsma Gaitniece

\section{The citizens of Liepāja city Teodors and Nikolajs Bredžs-Briedis} in business and engineering sciences

The article is dedicated to the citizens of Liepāja city Teodors Bredžs-Briedis (1885-1940) and Nikolajs Bredžs-Briedis (1909-1989) - father and son. Father Teodors Bredžs-Briedis was an entrepreneur in Liepāja city, but his son, Nikolajs, graduate of the Faculty of Chemistry (1936) of the University of Latvia, emigrated to the United States of America at the end of the Second World War. Nikolajs Bredžs-Briedis had a brilliant scientist's career - his research work in the metal welding industry was valued in 1955 by the Lincoln Gold Medal Award of the American Welding Society. In 1956, he was admitted to the US Honorary Society of Scientists and Researchers. Nikolajs Bredžs-Briedis has received 27 patents and is the author of 14 scientific publications.

Keywords: Teodors Bredžs-Briedis, Nikolajs Bredžs-Briedis, business, engineering sciences.

\section{Ласма Гайтниеие}

\section{Лиепайчане Теодор и Николай Бреджс-Бриедис в предпринимательстве и в инженерных науках}

Статья посвящена лиепайчанам Теодору и Николаю Бреджс-Бриедис отцу и сыну. Отец Теодор Бреджс-Бриедис (1885-1940) был предпринимателем в Лиепае - руководил цирк и кинотеатр. Его сын Николай Бреджс-Бриедис (1909-1989), выпускник Химического факультета Латвийского университета (1936), в конце Второй мировой войны эмигрировал в Соединенные Штаты Америки. Николай Бреджс-Бриедис создал блестящую карьеру ученого - его исследовательская работа в области сварки металла в 1955 году была оценена высшей наградой Американского общества по сварке - Золотой медалью Линкольна, в 1956 году - почетным дипломом Фонда Культуры Объединения латышей Америки за достижения в науке, а также в том же 1956 году ученый был принят в Почетном обществе ученых и исследователей США. Николай Бреджс-Бриедис получил 27 патентов и является автором 14 научных публикаций.

Ключевые слова: Теодор Бреджс-Бриедис, Николай Бреджс-Бриедис, предпринимательнская деятельность, инженерные науки. 